\title{
Peran Guru Agama dalam Meningkatkan Mutu Pembelajaran dengan Bantuan Multimedia
}

\author{
Talizaro Tafonao ${ }^{1}$, Yosua Budi Ristiono ${ }^{2}$ \\ Sekolah Tinggi Teologi KADESI Yogyakarta ${ }^{1}$, GBI Bukit Sion Temanggung ${ }^{2}$ \\ Email: talizarotafonao@gmail.com ${ }^{1}$, budi.ristiono@gmail.com ${ }^{2}$
}

\begin{abstract}
Abstrak
Kajian ini berangkat dari pengamatan penulis secara empiris dimana semua para guru di era digital ini ditantang untuk berubah ke arah inovasi, kreatif dan kompetitif yang disebut dengan era 4.0. Namun untuk sampai pada titik itu maka para guru harus berani keluar dari pola pengajaran yang kaku dan administratif. Oleh karena itu, para guru harus memiliki cara berpikir baru dalam menghadapi siswa di era digital, karena guru merupakan komponen penting dalam melaksanakan pembelajaran di sekolah. Selain memiliki pengaruh penting dalam pendidikan tersebut, guru harus menunjukkan keprofesionalnya dalam memanfaatkan segala media pembelajaran demi meningkatkan mutu pendidikan di sekolah. Lewat karya tulis ini, penulis mendorong para guru agama untuk memaksimalkan diri dalam mengggunakan teknologi sebagai alat bantu dalam melakukan proses pembelajaran sehingga menghasilkan output yang dapat mengikuti atau mengubah zaman menjadi lebih baik. Tidak ada alasan bagi para guru agama untuk berdalih sebagaimana yang telah ditemukan dalam penjelasan tulisan ini secara empiris. Sudah saatnya para guru meninggalkan proses pembelajaran yang cenderung mengutamakan media ceramah dan hafalan. Dengan menggunakan media pembelajaran yang tepat, maka peserta didik lebih siap dan percaya diri menghadapi berbagai tantangan dan perubahan yang ada di era revolusi industri 4.0.
\end{abstract}

Kata Kunci: Guru Agama, Mutu Pembelajaran, Multimedia

\section{The Role of Religion Teachers in Improving Learning Quality with Multimedia Assistance}

\author{
Talizaro Tafonao ${ }^{1}$, Yosua Budi Ristiono ${ }^{2}$ \\ Sekolah Tinggi Teologi KADESI Yogyakartal, GBI Bukit Sion Temanggung ${ }^{2}$ \\ Email: talizarotafonao@gmail.com ${ }^{1}$, budi.ristiono@gmail.com ${ }^{2}$
}

\begin{abstract}
This study is started from the author's empirical observation where all the teachers in the digital age are challenged to change towards innovation, creative and competitive called the 4.0 era. But to get that point, teachers must dare to get out of rigid and administrative teaching patterns. Therefore, teachers must have a new way of thinking in dealing with students in the digital age, because teachers are an important component in carrying out learning in schools. In addition to having an important influence in education, teachers must demonstrate their professionalism in utilizing all learning media to improve the quality of education in schools. Through this paper, the author encourage religious teachers to maximize themselves in using technology as a tool in conducting the learning process so as to produce outputs that can follow or change the times for the better. There is no reason for religious teachers to make excuses as has been found in the explanation of this paper empirically. It is time for teachers to leave the learning process which tends to prioritize lecture and rote learning media. By using appropriate learning media, students are better prepared and confident to face the challenges and changes that existed in the era of the industrial revolution 4.0.
\end{abstract}

Keywords: Religion Teacher, Learning Quality, Multimedia 


\section{PENDAHULUAN}

Pendidikan agama di sekolah memiliki peran penting dalam membangun akhlak (moral) peserta didik pada era digital ini. Alasan ini telah dituangkan dalam undang-undang Nomor 20 tahun 2003 bahwa pendidikan nasional berfungsi mengembangkan kemampuan dan membentuk watak serta peradaban bangsa yang bermartabat dalam rangka mencerdaskan kehidupan bangsa, bertujuan untuk berkembangnya potensi peserta didik agar menjadi manusia yang beriman dan bertakwa kepada Tuhan Maha Esa, berakhlak mulia, sehat, berilmu, cakap, kreatif, mandiri, dan menjadi warga negara yang demokaratis serta bertanggung jawab (Abidin et al., 2018). Itulah sebabnya pendidikan agama di sekolah sangat penting dalam membentuk setiap karakter pribadi peserta didik.

Namun untuk merealisasikan hal ini maka diperlukan peran seorang guru agama dalam meningkatkan mutu pembelajaran agama di sekolah. Guru merupakan komponen penting dalam proses pembalajaran agama di sekolah, karena tugas guru agama memiliki tanggung jawab moral dalam mempengaruhi dan membawa peserta didik ke jalan yang benar. Untuk itu, guru dalam melakoni panggilannya harus melaksanakan dengan penuh tanggung jawab, terutama bertanggung jawab terhadap Tuhan yang mempercayakan pekerjaan itu (Tafonao, 2019). Kitab suci menekankan bahwa "Didiklah orang muda menurut jalan yang patut baginya, maka pada masa tuanyapun ia tidak akan menyimpang dari pada jalan itu. (Amsal 22:6). Berdasarkan penjelasan ini, maka diperlukan proses pembelajaran yang baik dari guru, karena proses pembelajaran merupakan salah satu sarana yang dipakai oleh guru dalam melakukan pengajaran dan pembimbingan kepada peserta didik, sehingga mengalami suatu perubahan yakni kognitif, afektif dan psikomotorik.

Dengan mencapai hal itu, maka proses pembelajaran sebaiknya ditingkatkan, oleh karena itu para guru dan peserta didik harus sama-sama terlibat secara aktif dalam proses pembelajaran tersebut. Suasana pembelajaran hendaknya dibuat dua arah, bukan hanya pengajar yang mendominasi percakapan, tetapi diupayakan ada komunikasi dua arah yang seimbang. Misalnya pada waktu penulis mengajar program strata dua di Surabaya pada tanggal 2-5 Desember 2019, penulis melakukan pengajaran dua arah, dimana mahasiswa diberi kesempatan untuk menyampaikan argumennya terhadap materi yang sudah dipelajarinnya. Selain itu, mahasiswa diberi kesempatan untuk mempresentasikan hasil kajian terhadap setiap materi. Pembelajaran seperti ini sangat efektif dan menyenangkan serta memberi kesempatan seluasluasnya kepada siswa untuk belajar. Tujuannya adalah untuk membantu siswa dalam memahami konsep yang sedang dipelajari (Afifatu, 2015).

Selain proses-proses di atas, maka hendaknya dibuat metode pembelajaran yang variatif dan beragam sehingga membuat peserta didik lebih mudah menangkap materi ajar. Salah metode yang perlu digunakan adalah media pembelajaran. Dengan menggunakan media pembelajaran maka terjadi proses komunikasi dari pembawa pesan kepada penerima pesan (Nurseto, 2019). Dalam menyampaikan pesan seorang komunikator tidak terpisahkan dari media dalam menyampaikan pesan tersebut. Maka dalam melakukan pengajaran perlu media pembelajaran. Sebab pemanfaatan media dalam pengajaran seharusnya merupakan bagian yang harus mendapat perhatian dari guru sebagai fasilitator dalam setiap kegiatan pembelajaran (Talizaro, 2018). Oleh sebab itu perlu memilih media yang sesuai dengan tingkat perkembangan, konteks dan pemikiran komunikan. Hal tersebut sangat penting karena pemilihan media yang kurang tepat justru dapat menghambat proses penyampaian pesan yang baik. Media pembelajaran perlu mendapat perhatian yang cukup serius dari para pengajar karena pada akhirnya akan menentukan seberapa besar mutu (kualitas) pembelajaran yang disampaikan seorang guru khususnya dalam aspek rohani, intelek, emosi, perilaku dan kehendak (Sidjabat, 2017).

Namun ada beberapa persoalan lain mengapa masih ditemukan beberapa guru yang tidak mengembangkan media pembelajaran di sekolah. Salah satu alasannya adalah: (1) Guru tidak ada kreatif dalam mengembangkan media 
secara visual karena tidak bisa mengoperasikan komputer; (2) Guru jarang menggunakan media visual didalam proses pembelajaran karena tidak ada fasilitas yang memadai (LCD); (3) Sebagian besar guru tidak ada kasiapan dalam mengajar sehingga media visual dalam pembelajaran jarang dipakai (Rusby, 2017).

Selain alasan dan persoalan di atas, penulis mencoba berdiskusi dengan beberapa mahasiswa yang sudah menyelesaikan PKL di sekolah selama satu semester pada bulan Januari 2019. Menurut penuturan mahasiswa ini bahwa ada beberapa kendala dalam menggunakan media pembelajaran pada saat melakukan proses pembelajaran di kelas, yaitu (1) pada jam belajar agama anak-anak sering kali belajar diperpustakaan, (2) fasilitasi masih minim, sehingga mahasiswa tersebut menggunakan media apa adanya seperti menggambar, mendengar ceramah, mendengar musik melalui handphone dan menonton vedeo dileptop ala kadarnya, (3) kesiapan dalam mengajar tidak maksimal karena situasi tidak mendukung.

Kejadian ini bukan hanya cerita, namun hal itu benar adanya pada saat penulis mengunjungi salah satu mahasiswa PKL pada bulan September 2018 di salah satu SMP di Yogyakarta, penulis memantau mahasiswa yang sedang mengajar di kelas tanpa ada LCD, Papan tulis dan meja guru. Dengan kondisi seperti ini sudah pasti para guruguru terbatas dalam mengembangakan media. Makanya tidak heran kalau mutu pembelajaran kurang maksimal dan cenderung semakin menurun karena kasiapan fasilitasinya tidak mendukung. Sehebat apapun guru jika di sekolah tersebut tidak all out dalam mendukung dari segi fasilitas maka semua akan jadi sia-sia.

Kajian ini sangat beralasan untuk dapat dipahami dalam mengatasi segala kekurangan tersebut agar semua peran terlibat dalam memajukan pembelajaran yang bermutu. Tidak ada alasan bagi guru untuk tidak berpikir keras dalam mengatasi setiap persoalan tersebut khusunya guru agama di sekolah-sekolah. Kehadiran guru-guru di sekolah sangat berarti bagi peserta didik sekalipun banyak keterbatasan.

Berkaitan dengan penjelasan di atas maka hal ini juga berlaku bagi guru pendidikan agama
Kristen. Panggilannya sebagai seorang pengajar semestinya juga harus memanfaatkan media pembelajaran, supaya pengajarannya menjadi efektif sekalipun ada banyak kesulitan dan keterbatasan yang dihadapi. Dalam Perjanjian Baru, karunia mengajar dapat dipahami dari pelayanan Yesus Kristus (Telaumbanua, 2018). Matius 7:38, 12:23, 13:54 mencatat bahwa orangorang yang diajar oleh Tuhan Yesus menjadi takjub atas pengajaran-Nya. Pengajaran-Nya begitu berkualitas, sangat berdampak dalam mengubah dunia dan melahirkan para pemimpin besar pada jamannya dan sampai saat ini. Hal tersebut tentu tidak terlepas dari pemanfaatan media pembelajaran yang dipakai oleh Tuhan Yesus dalam mengajar. Menjadi tantangan terbesar bagi guru pendidikan agama Kristen saat ini adalah meningkatkan kualitas pembelanjaran dengan bantuan media pembelajaran yang efektif, sehingga dapat meningkatkan kualitas pembelajaran dan mencapai tujuan pembelajaran agama yang baik.

Berdasarkan latar belakang di atas maka penulis mengkaji "Peran Guru Agama Dalam Meningkatkan Mutu Pembelajaran dengan Dengan Bantuan Multimedia. Adapun rumusan masalah dalam penulisan ini sebagai berikut: (1) Apakah peran seorang guru agama Kristen dalam meningkatkan mutu pembelajaran telah tercapai melalui bantuan media pembelajaran? (2) Hal apakah yang perlu dipertimbangkan seorang guru agama Kristen dalam pemilihan media pembelajaran agar pemanfaatannya efektif ?. Dengan tujuan yakni (1) Untuk mengetahui peran seorang guru agama dalam meningkatkan mutu pendidikan pendekatan media pembelajaran, (2) Untuk mengetahui hal-hal yang perlu dipertimbangkan oleh seorang guru agama dalam pemilihan media agar pemanfaatannya lebih efektif.

\section{PEMBAHASAN}

\section{Peran dan Fungsi Guru Agama Kristen dalam Pendidikan}

Pendidikan dalam bahasa latin dipakai kata educare yang artinya merawat, membesarkan, memelihara dan memperkaya seseorang dengan gizi yang baik supaya bertumbuh sehat dan kuat. 
Kata kedua yang dipakai untuk menyebut pendidikan adalah educere yang artinya menuntun seseorang keluar dari suatu keadaan atau situasi kedalam situasi yang lebih baik. Berdasarkan pengertian tersebut maka peran seorang guru Kristen adalah merawat, membesarkan, memelihara dan memperkaya peserta didik dengan pengetahuan dan pemahaman yang benar agar bertumbuh sehat dan kuat serta berkembang menuju sebuah keadaan yang lebih baik sebagai perwujudan dari imannya dalam realitas kehidupan. Oleh karena itu, fungsi dari guru Pendidikan Agama Kristen adalah menjadi pembimbing rohani bagi anak didik dengan dasar kasih sayang yang iklas (Sahartian, 2018). Namun perlu diperhatikan bahwa seorang pendidik bukan hanya memberikan pengetahuan kognitif, tetapi juga pemahaman afektif, moral dan spiritual. Pembentukan moral dan watak peserta didik seharusnya menjadi perhatian seorang pendidik, baik moral secara pribadi maupun moral sosial dan moral terhadap lingkungan kehidupan sehingga imannya dapat diwujud dalam realitas kehidupan sehari-hari.

Berdasarkan penjelasan itu maka ada tujuh istilah yang digunakan untuk menjelaskan tugastugas seorang guru berdasarkan undang-undang Guru dan Dosen No. 14 Tahun 2005 Bab 1 Pasal 1, ayat 1 yaitu: mendidik, mengajar, membimbing, mengarahkan, melatih, menilai dan mengevaluasi. Selain itu, ada beberapa fungsi guru menurut Zen yaitu: sebagai informator, sebagai pelaksana cara mengajar informatif, laboratorium, studi lapangan dan sumber informasi kegiatan akademik maupun umum; Sebagai organisator, pengelola kegiatan akademik, silabus, work shop, jadwal pelajaran dan lain-lain (Zen, 2010). Guru harus dapat merangsang dan memberikan dorongan serta reinforcemen untuk mendinamisasikan potensi siswa, menumbuhkan swadaya, sehingga akan terjadi dinamika di dalam pembelajaran; sebagai pengarah/director, jiwa kepemimpinan bagi guru dalam peranan ini lebih menonjol karena guru harus dapat membimbing dan mengarahkan kegiatan siswa sesuai dengan tujuan yang dicitacitakan; sebagai inisiator, guru berfungsi sebagai pencetus ide-ide dalam belajar dalam belajar.
Selain itu, guru berfungsi dalam menentukan langkah, bersifat sabar, teladan, serta tanggap terhadap situasi dan kondisi yang dihadapi oleh siswa (Hasyim, 2014). Guru bertindak selaku penyebar kebijakan pendidikan dan pengetahuan. Misalnya pada bulan Mei 2019 yang lalu, penulis menghadapi beberapa mahasiswa yang mengalami kesulitan dalam menulis Skripsi dan Tesis. Sebagai pembimbing memiliki tanggung jawab penuh untuk mengarahkan agar mahasiswa tersebut memiliki semangat untuk menulis. Penulis tidak hanya bertanggung jawab sampai disitu tetapi penulis juga bertanggung jawab sampai mahasiswa menemukan solusinya dalam mendapatkan referensi seperti buku-buku dan jurnal.

Artinya guru sebagai mediator kepada siswa dalam menfaatkan media yang ada agar siswa tidak mengalami kesulitan dalam mengerjakan tugastugas yang ada. Oleh karena itu, hendaknya para guru meningkatkan kualitas dirinya dan karyanya supaya dapat menunaikan tugas mengajar secara efektif (Sidjabat, 2017). Hal ini menjadi tantangan bagi guru-guru agama Kristen untuk dapat melakukan evaluasi diri menyangkut kualitas diri dan karyanya dalam menjalankan fungsi dan perannya sebagai seorang pengajar. Peran dan fungsi yang begitu penting dalam dunia pengajaran agama Kristen mestinya harus terus ditingkatkan dari sisi mutu atau kualitas. Makanya penulis selalu membagikan pengalaman menulis kepada mahasiswa di kelas. Dengan cara menyuruh mahasiswa membuka google scholar dan melihat beberapa karya tulis yang tertera nama penulis di sana. Jadi selain guru berperan sebagai pengajar, namun guru juga telah menggunakan media teknologi dalam mengajar, dimana siswa belajar memanfaat internet atau google sebagai sumber belajar.

\section{Peran Guru Agama dalam Peningkatan Mutu Pendidikan Agama Kristen}

Dalam Kemendikbud (2014:7) istilah mutu pendidikan adalah kemampuan sekolah dalam pengelolaan sekolah secara operasional dan efisien terhadap komponen-komponen yang berkaitan dengan sekolah, sehingga menghasilkan nilai tambah terhadap komponen tersebut menurut 
norma atau standar yang berlaku" (Sastrawan, 2018)

Berdasarkan definisi tersebut, dalam konteks pendidikan agama Kristen maka mutu pendidikan Kristen dapat didefinisikan sebagai kemampuan sekolah dalam pengelolaan sekolah secara operasional dan efisien terhadap komponenkomponen yang berkaitan dengan sekolah, sehingga menghasilkan nilai tambah menurut standar yang berlaku dalam bidang pendidikan agama Kristen. Oleh sebab itu mutu pendidikan agama Kristen sangat terkait dengan kemampuan yang dimiliki oleh guru dalam penyelenggaraan pembelajaran secara efektif dan efisien, sehingga menghasilkan manfaat yang bernilai tinggi bagi pencapaian tujuan pendidikan agama Kristen. Pertanyaan yang perlu dijawab berikutnya apa yang menjadi standard yang berlaku dalam bidang pendidikan agama Kristen.

Thomas H. Groome berpendapat bahwa tujuan pendidikan agama Kristen adalah untuk mensponsori orang-orang ke arah iman Kristen yang dewasa sebagai realitas hidup (Groome, 2017). Howard G. Hendricks dalam Sidjabat (2011) mengemukakan "teaching to change lives" atau "mengajar untuk menghasilkan perubahan hidup secara menyeluruh" (Sidjabat, 2017). Jadi jelas, konsep standar yang berlaku dalam bidang pendidikan agama Kristen adalah terjadinya perubahan hidup para peserta didik yang mewujudkan imannya menjadi sebuah realitas hidup, ada perubahan hidup secara menyeluruh sebagai perwujudan imannya kepada Kristus.

Sebagaimana yang telah diketahui bahwa hal yang sangat penting dalam rangka meningkatkan mutu pendidikan di sekolah adalah peran, fungsi dan tanggung jawab guru, mengingat guru merupakan orang yang secara langsung berhadapan dengan peserta didik dalam melaksanakan kegiatan pembelajaran, sehingga pada akhirnya out put pendidikan dapat dirasakan oleh masyarakat. Keadaan tersebut dapat terlaksana apabila ditunjang dengan adanya upaya peningkatan kemampuan guru dalam mengelola dan berperan langsung dalam mengajar serta mendidik para siswanya. Guru merupakan pelaksana terdepan pendidikan anak-anak di sekolah. Oleh karena itu berhasil tidaknya upaya peningkatan mutu pendidikan banyak ditentukan juga oleh kemampuan yang ada pada guru dalam mengemban tugas pokok sehari-harinya yaitu pengelolaan pembelajaran di sekolah. Salah satu peranan dan fungsi guru dalam meningkatkan mutu pendidikan yaitu guru sebagai mediator dan fasilitator berfungsi untuk memperagakan suatu media atau alat pembelajaran yang mendukung materi sehingga siswa lebih merasa jelas (Usman, 2010). Oleh karena itu guru hendaknya memiliki pengetahuan dan pemahaman yang cukup tentang media pendidikan sebagai alat komunikasi guna mengefektifkan pembelajaran. Sangat jelas bahwa media pembelajaran sangat penting sebagai jembatan yang menghubungkan guru dengan peserta didik. Meskipun dalam realitas pelaksanaan seorang guru agama Kristen akan dihadapkan pada keterbatasan media pembelajaran yang tersedia, tetapi dengan persiapan dan perencanaan yang detil akan membuat pemilihan media pembelajaran menjadi tepat dan membawa dampak yang signifikan terhadap peningkatan mutu pendidikan agama Kristen di sekolah.

\section{Multimedia sebagai Sarana Peningkatan Mutu Pembelajaran}

Media pembelajaran merupakan segala sesuatu yang dapat digunakan untuk menyalurkan pesan pengirim kepada penerima, sehingga dapat merangsang pikiran, perasaan, perhatian, dan minat peserta didik untuk belajar (Talizaro, 2018). Pendapat lain dari Ruth Lautfer (1999), mengatakan bahwa media pembelajaran adalah salah satu alat bantu mengajar bagi guru untuk menyampaikan materi pengajaran, meningkatkan kreatifitas siswa dan meningkatkan perhatian siswa dalam proses pembelajaran (Talizaro, 2018). Sehingga Media pembelajaran dapat diartikan sebagai segala sesuatu yang dapat digunakan untuk menyampaikan materi pengajaran, meningkatkan kreatifitas siswa dan meningkatkan perhatian siswa dalam proses pembelajaran sehingga dapat merangsang pikiran, perasaan, perhatian, dan minat peserta didik untuk belajar.

Ada beberapa pendapat mengenai jenis dan karakteristik media pembelajaran yang dapat 
dipilih seorang guru dalam mengelola proses pembelajaran. Bertolak dari pendapat Edgar Dale, B.S. Sidjabat (2017) menggolongkan media pembelajaran sebagai berikut: media yang berupa pengalaman langsung, media yang berupa benda dan kegiatan tiruan, media yang berupa dramatisasi tindakan, media yang berupa karyawisata, media televisi, media yang berupa foto-foto dan brosur, media siaran radio, media yang berupa gambar, lukisan, bagan atau grafik, media yang berupa ungkapan dan kalimat yang dipergunakan guru dalam mengajar (Sidjabat, 2017). Sebagai tujuan dari media adalah agar dapat digunakan untuk menyalurkan pesan dari pengirim ke penerima pesan sehingga dapat merangsang pikiran, perasaan, perhatian dan minat siswa sedemikian rupa sehingga proses belajar terjadi" (Febriyanto \& Yanto, 2019).

Berdasarkan berberapa jenis dan karakteristik media pembelajaran tersebut di atas, maka seorang guru agama Kristen dalam perananya sebagai mediator dan fasilitator harus mempertimbangkan secara sungguh-sungguh media yang akan dipilih untuk mengajar. Semakin tepat media pembelajaran yang dipilih maka proses pembelajaran dan mutu pembelajaran akan semakin meningkat untuk mencapai tujuan pendidikan agama Kristen yaitu adanya perubahan secara menyeluruh dari peserta didik sebagai wujud nyata imannya kepada Kristus yang semakin dewasa dalam realitas hidup.

\section{Media Pembelajaran dalam Alkitab}

Alkitab merupakan sumber pengajaran utama yang diakui tanpa salah oleh setiap orang percaya. Didalamnya terdapat rujukan-rujukan pemakaian media dalam cara Allah berkomunikasi kepada manusia. Sidjabat mengatakan bahwa Alkitab mengkomunikasikan bahwa Allah mendidik manusia melalui media (Sidjabat, 2017). Kejadian pasal tujuh memberitahu kepada kita bahwa Allah memakai air bah sebagai media untuk menyampaikan pesan tentang arti penting kekudusan, kebenaran dan keadilan Allah. Bahtera dijadikan media oleh Allah untuk mendidik Nuh hidup dalam ketaatan akan perintah Tuhan, perlindungan Tuhan dan kasih Tuhan akan keberlangsungan hidup manusia dan semua binatang yang ada di dalamnya.

Keluaran 14:1-31 memberitahukan bahwa Allah memakai peristiwa terbelahnya laut Terberau untuk menunjukkan kebesaran-Nya, bahwa tidak ada yang mustahil bagi Allah untuk menolong umat-Nya. Kejadian 41 mengisahkan ketika Allah memakai mimpi sebagai media untuk menyampaikan hal-hal yang akan terjadi di masa depan. Menyatakan rencana Allah melalui Yusuf memelihara umat pilihannya dalam kelaparan yang panjang. Kehidupan Hosea yang menikah dengan pelacur sebagai media Allah memberitahu bahwa Israel telah berzina secara rohani dan berpaling kepada dewa-dewa asing dan tidak setia kepada Allah.

Regina M. Alfonso dalam (Sidjabat, 2017) 2011) mengemukakan bahwa Tuhan Yesus juga menggunakan media ketika mengajar (Sidjabat, 2011). Berikut contoh penggunaan media yang dilakukan oleh Tuhan Yesus, yaitu:

Pertama, Ketika mengajar murid-murid-Nya agar mereka bersikap rendah hati satu sama lain Ia menghadirkan anak kecil di tengah-tengah mereka (Matius 18:2, Markus 19:36, Lukas 9:46-48). Kedua, Untuk menegaskan bahwa iman dan percaya sangat penting bagi jawaban doa, Yesus mengutuk pohon ara yang tidak berbuah hingga layu (Markus 11:12-14, 20-24). Ketiga, Untuk mengajarkan bahwa setiap orang harus membayar pajak dan memberikan persembahan kepada Allah Ia memakai media mata uang (Matius 22:15-22). Keempat, Untuk mengusir setan bernama Legion dari seseorang 2000 ekor babi dijadikan media untuk menggambarkan betapa berharganya nilai jiwa seseorang yang harus diselamatkan. Kelima, Untuk menyadarkan kedua murid yang berjalan ke Emaus bahwa Ia telah bangkit, Yesus mendengarkan mereka, bertanya jawab, memecah roti dan memberikan kepada mereka, sampai mereka tersadar bahwa itu adalah Tuhan Yesus.

Nyata bahwa Kristus sebagai sang guru Agung yang menjadi teladan bagi setiap orang percaya menggunakan media dalam mengajarkan kebenaran kepada setiap orang. Media yang digunakan cukup variatif menyesuaikan dengan materi yang akan disampaikan. Oleh sebab itu 
pemakaian media pembelajaran oleh guru Kristen merupakan sesuatu yang alkitabiah dan merupakan keteladanan yang dicontohkan oleh Yesus Kristus sendiri.

\section{Dasar Pertimbangan dan Prinsip Pemilihan Media}

Di bagian sebelumnya telah dijelaskan bahwa Tuhan Yesus menggunakan media berupa benda, orang, alam, tindakan, kejadian atau peristiwa. Teladan kreatif Yesus Sang Guru, hendaknya menjadi sumber inspirasi bagi bagi guru (Sidjabat, 2017). Tuhan Yesus seharusnya dijadikan sebagai contoh atau model untuk mengajar yang hidup dan patut dijadikan teladan. Ia sangat cakap mengajar, Ia menggunakan metode-metode secara leluasa dan efisien (M. Price, 2011). Hal tersebut dapat dipastikan bahwa Dia sudah mempertimbangkan banyak faktor sehingga pengajaran-Nya menjadi efektif dan efisien. Media pembelajaran yang dipilih Tuhan Yesus tepat dan sampai pada tujuan pembelajaran.

Pada zaman ini model dan bentuk media yang akan digunakan oleh guru agama Kristen mungkin tidak selalu harus sama dengan yang dipakai oleh Tuhan Yesus. Hal itu itu dapat disesuaikan dengan situasi dan kondisi pada saat ini. Beberapa pertimbangan yang sering dipakai guru dalam memilih media pembelajaran, yaitu: merasa sudah akrab dengan media itu, media yang dipilihnya dapat menggambarkan dengan lebih baik daripada dirinya sendiri, media yang dipilihnya dapat menarik minat dan perhatian siswa, serta menuntutnya pada penyajian yang lebih testruktur dan terorganisir, Ingin memberi gambaran atau penjelasan yang lebih konkret (AzharArsyad, 2007). Mc. Connel dalam Arif S. Sadiman dkk (2012), menyampaikan beberapa faktor yang perlu dipertimbangkan dalam pemilihan media pembelajaran, yaitu: tujuan instruksional yang ingin dicapai, karakteristik siswa atau sasaran, jenis rangsangan belajar yang diinginkan (audio, visual, gerak, dan seterusnya), keadaan latar atau lingkungan, kondisi setempat dan luasnya jangkauan yang ingin dilayani. Faktorfaktor tersebut pada akhirnya harus diterjemahkan dalam keputusan pemilihan media (Sadiman,
2012). Menurut Ford (1987) dalam Sidjabat ada lima faktor yang perlu dipertimbangkan guru dalam memilih media pembelajaran, yaitu: tujuan mengajar, kemampuan murid untuk menyerap pesan melalui media, fasilitas media yang tersedia, waktu yang tersedia, dan biaya (Sidjabat, 2017).

Berdasarkan beberapa pendapat di atas pemilihan media pembelajaran hendaknya tidak dilakukan secara sembarangan, melainkan didasarkan atas pertimbanganpertimbangan meliputi tujuan yang ingin dicapai, karakteristik siswa atau sasaran pendidikan, jenis rangsangan belajar yang diinginkan (audio, visual, gerak, dan seterusnya), alokasi waktu dan sumber, keadaan latar atau lingkungan, kondisi setempat dan luasnya jangkauan yang ingin dilayani. Kesalahan pada saat pemilihan tanpa adanya pertimbangan yang tepat, baik pemilihan jenis media maupun topik yang dimediakan, akan membawa akibat proses pembelajaran terganggu, penurunan kualitas pembelajaran dan pencapaian tujuan pendidikan agama Kristen yang tidak optimal.

Pemilihan media pembelajaran yang sesuai dengan standar kompetensi dan indikator yang ditetapkan pada dasarnya merupakan suatu perluasan keterampilan berkomunikasi yang membutuhkan suatu proses yang rinci, sistematis dan khusus. Memilih media pembelajaran yang terbaik untuk standar kompetensi dan indikator suatu pembelajaran bukan suatu pekerjaan yang mudah. Karena pemilihan media tersebut didasarkan pada berbagai prinsip dan faktor yang saling mempengaruhi.

Ada beberapa prinsip dalam memilih media pembelajaran yang harus diperhatikan oleh seorang guru agama Kristen. Menurut M. Khali secara garis besar ada 3 prinsip yang perlu diperhatikan dalam pemilihan media pembelajaran (Khali, 2015), yaitu: (1) Harus adanya kejelasan tentang maksud dan tujuan pemilihan media pembelajaran. Apakah pemilihan media itu untuk pembelajaran, untuk informasi yang bersifat umum, ataukah sekedar hiburan saja mengisi waktu kosong. Lebih khusus lagi, apakah untuk pembelajaran kelompok atau individu, apakah sasarannya siswa TK, SD, 
SMA, atau siswa Sekolah Dasar Luar Biasa, masyarakat pedesaan ataukah masyarakat perkotaan. (2) Karakteristik Media Pembelajaran. Setiap media pembelajaran memiliki karakteristik tertentu, baik dilihat dari keunggulannya, cara pembuatan maupun cara penggunaannya. Memahami karakteristik media pembelajaran merupakan kemampuan dasar yang harus dimiliki dalam kaitannya dengan pemilihan media pembelajaran. Disamping itu, hal ini memberikan kemungkinan bagi kita untuk menggunakan berbagai media pembelajaran secara bervariasi. (3) Alternatif Pilihan, yaitu adanya sejumlah media yang dapat dibandingkan atau dikompetisikan. Dengan demikian kita bisa menentukan pilihan media pembelajaran mana yang akan dipilih. Selanjutnya perlu diingat bahwa tidak ada satu mediapun yang sifatnya bisa menjelaskan semua permasalahn atau materi pembelajaran secar tuntas.

\section{Pemilihan Media Pembelajaran}

Setiap media pembelajaran memiliki keunggulan masing-masing, maka dari itulah seorang guru diharapkan dapat memilih media yang sesuai dengan kebutuhan atau tujuan pembelajaran. Dengan harapan bahwa penggunaan media akan meningkatkan mutu pembelajaran. Itulah sebabnya guru dituntut untuk mengembangkan keterampilan membuat media pembelajaran yang akan digunakan dalam setiap proses pembelajaran (Rusby, 2017). Dalam perannya sebagai pengajar, seorang guru agama Kristen mengelola kegiatan agar peserta didiknya belajar. Hal itu meliputi persiapan, merencanakan tujuan dan kompetensi yang menjadi arah pembelajaran. Salah satu hal penting yang harus dipersiapkan dan direncanakan dengan baik adalah memilih media pembelajaran yang tepat agar mutu pembelajaran meningkat. Dengan adanya media maka mengkongkritkan yang abstrak sehingga dapat mengurangi terjadinya penyakit verbalisme (Tejo, 2011).

Hal-hal lain yang perlu diperhatikan dalam memilih media pembelajaran adalah memahami karakteristik setiap media, sesuai dengan tujuan yang hendak dicapai, sesuai dengan metode pelajaran yang digunakan, sesuai dengan materi yang dikomunikasikan, sesuai dengan keadaan siswa, sesuai dengan situasi dan kondisi lingkungan, kemudahan memperoleh media, sesuai dengan keterampilan guru yang menggunakannya, ketersediaan waktu menggunakannya, sesuai dengan taraf berfikir siswa.

Dalam hal inilah peran seorang guru agama Kristen begitu penting dalam meningkatkan mutu pembelajaran melalui media pembelajaran. Seorang guru agama Kristen harus memahami jenis dan karakteristik media, memiliki dasar pertimbangan dan kriteria yang jelas dalam memilih media, dan memahami prinsip pemilihan media yang tepat dalam proses pengajaran yang akan dilakukan. Karena pada dasarnya pembelajaran berbasis multimedia melibatkan hampir semua unsur-unsur indra dan dapat mempermudah siswa dalam belajar, karena waktu yang digunakan lebih efektif dan efisien (Surasmi, 2016).

\section{SIMPULAN DAN SARAN}

Tulisan ini hadir sebagai upaya dalam menjelaskan peran guru agama dalam meningkatkan mutu pembelajaran melalui bantuan multimedia. Keberhasilan pembelajaran agama di sekolah sangat ditentukan oleh kemampuan seorang guru dalam memanfaatkan setip media yang ada. Untuk itu, dalam meningkatkan mutu pembelajaran di sekolah hendaknya guru mengupayakan perannya dalam mengembangkan media tersebut, sehingga peserta didik tidak mengalami kejenuhan dalam mengikuti proses pembelajaran. Guru tidak boleh menutup diri terhadap perkembangan teknologi, justru dengan kehadiran teknologi saat ini dapat menolong para guru dalam mendapatkan berbagai informasi yang sedang berkembang.

Selain terbuka dengan segala kemajuan tersebut, guru harus mampu membangun komunikasi yang efektif dalam proses pembelajaran yang berbasis teknologi. Namun yang tidak kalah penting dalam kajian ini adalah (1) guru mampu memahami karakter siswa termasuk aspek fisik, sosial budaya, emosional dan intelektual. (2) guru mampu memilih media pembelajaran yang tepat dan efektif yang 
disesuaikan dengan kondisi peserta didik. (3) Guru selalu mengupdate diri terhadap inovasi baru dalam mempersiapkan media pembelajaran. Hal ini merupakan kebutuhan yang mendesak dan sangat diperlukan dalam pembelajaran berbasis digital sehingga siswa dapat langsung berinteraksi dengan gurunya sendiri dalam pembelajaran yang menyenangkan, sehingga akhirnya guru tersebut diberi lebel adalah guru yang profesional.

Berdasarkan pembahasan tentang Peran Guru Agama Dalam Meningkatkan Mutu Pembelajaran Dengan Bantuan Multimedia maka saran penulis kepada para guru agama harus lebih kreatif dalam menggunakan media yang sudah tersedia. Kekreatifitas para guru dapat menolong siswa untuk lebih serius dalam menerima pembelajaran. Oleh karena itu, hendaknya pihak sekolah dapat menyediakan sarana prasarana bagi para guru untuk meningkatkan mutu pembelajaran di sekolah.

Penulis menyadari bahwa kajian ini masih memiliki kekurangan sini sana termasuk dalam penyajian teori, sumber dan data. Oleh karena itu, kajian ini disarankan untuk dilakukan pengkajian lebih lanjut.

\section{DAFTAR REFERENSI}

Abidin, Zaenal, Nurhayati, Fatimah, Lestari, Niken, ... Dwi. (2018). Akhlak Mulia Ditinjau Dari Pendidikan Agama Islam dalam keluarga. 85-92.

Afifatu, R. (2015). Efektivitas Pembelajaran. Jurnal Pendidikan Usia Dini, 9(1), 15-32. https://doi.org/DOI: https://doi.org/10.21009/JPUD.091.02

AzharArsyad. (2007). Media Pembelajaran. Jakarta: Raja Grafindo Persada.

Febriyanto, B., \& Yanto, A. (2019). Penggunaan media Flash Card untuk Meningkatkan Hasil Belajar Siswa Sekolah Dasar. Jurnal Komunikasi Pendidikan, $\quad 3(2), \quad 108$. https://doi.org/10.32585/jkp.v3i2.302

Groome, T. H. (2017). Christian Religious Education. Jakarta: BPK: Gunung Mulia.

Hasyim, M. H. M. (2014). Penerapan Fungsi Guru Dalam Proses Pembelajaran. AULADUNA: Jurnal Pendidikan Dasar Islam, 1(2), 265-276. Retrieved from http://journal.uin- alauddin.ac.id/index.php/auladuna/article/view/55 $6 / 557$

Khali, M. (2015). Media Pembelajaran. Yogyakarta: Aswaja Persindo.

M. Price. (2011). Jesus The Teacher. Bandung: Lembaga Literatur Baptis.

Nurseto, T. (2019). Membuat Media Pembelajaran yang Menarik. Jurnal Ekonomi Dan Pendidikan, 1935. https://doi.org/10.21831/jep.v8i1.706

Rusby, Z. et al. (2017). Upaya Guru Mengembangkan Media Visual dalam Proses Pembelajaran Fiqih di MAN Kuok Bangkinang Kabupaten Kampar. AlHikmah, 14(1), 18-37.

Sadiman, A. S. (2012). Media Pendidikan Pengertian, Pengembangan, dan Pemanfaatannya. Jakarta: PT Raja Grafindo Persada.

Sahartian, S. (2018). Pemahaman Guru Pendidikan Agama Kristen Tentang II Timotius 3:10 Terhadap Peningkatan Kecerdasan Spiritual Anak Didik. FIDEI: Jurnal Teologi Sistematika Dan Praktika, 1(2), 146-172. https://doi.org/10.34081/fidei.v1i2.15

Sastrawan, K. B. (2018). Profesionalisme Guru Dalam Upaya. Jurnal Penjaminan Mutu, 2(2), 65-73.

Sidjabat, B. S. (2011). Mengajar Secara Profesional. Bandung: Kalam Hidup.

Sidjabat, B. S. (2017). Mengajar secara Profesional. Bandung: Kalam Hidup.

Surasmi, W. A. (2016). Pemanfaatan Multimedia untuk Mendukung Kualitas Pembelajaran. Temu Ilmiah Nasional Guru (TING) VIII, (November), 593607-Halaman 597. Retrieved from wuwuh@ut.ac.id

Tafonao, T. (2019). Peran Guru Dalam Menangani Perilaku Menyimpang di Kalangan Siswa Millenial. Media Edukasi Indonesia (Anggota IKAPI), 53(9), 164-179. https://doi.org/10.1017/CBO9781107415324.004

Talizaro, T. (2018). PERANAN MEDIA PEMBELAJARAN DALAM MENINGKATKAN MINAT BELAJAR MAHASISWA. Jurnal Komunikasi Pendidikan, Vol.2 No.2, Juli 2018 P. ISSN 2549-1725 E-ISSN 2549-4163, 2(2).

Tejo, N. (2011). Membuat Media Pembelajaran yang Menarik. Jurnal Ekonomi \& Pendidikan.

Telaumbanua, A. (2018). Peranan Guru Pendidikan Agama Kristen Dalam Membentuk Karakter Siswa. FIDEI: Jurnal Teologi Sistematika Dan Praktika, 1(2), 219-231. https://doi.org/10.34081/fidei.v1i2.9

Usman. (2010). Menjadi Guru Profesional. Bandung: Angkasa.

Zen. (2010). Peranan Guru dalam Proses Belajar Mengajar. Jakarta: Gramedia. 